\title{
Interpretation of "Wuthering Heights" from the Perspective of Eco-criticism
}

\author{
Haiou Pan \\ College of Foreign Languages, Liaoning University of Traditional Chinese Medicine, Shenyang, 110847, \\ China
}

30662238@qq.com

Keywords: Wuthering Heights; eco-criticism; natural ecology; social ecology; spiritual ecology

\begin{abstract}
Ecological criticism is a literary criticism that explores the relationship between literature and nature, enriches the ecological meaning of literature, reveals the ecological limitations of literature, promotes the establishment of ecological literary concepts and ecological aesthetic concepts, and encourages people to form and strengthen ecological awareness and promote ecology civilization construction. "Wuthering Heights" is a rich and literary classic, expressing the ecological thought of returning to nature and returning to nature. It embodies the relationship between civilization and nature, and contains profound ecological wisdom. This paper uses western ecological criticism theory to analyze the description of natural ecology, social ecology and spiritual ecology in the novel, revealing the critique of civilization, the longing for harmonious relationship between man and nature, and the theme of exploring ecological balance, and advocate people to return to nature, but also to live in the true colors.
\end{abstract}

\section{Introduction}

Emily Jane Bronte (1818-1848), a famous British woman writer and poetess of the Victorian era, was praised by Marx as a modern British outstanding novelist by Charles John Huffam Dickens and William Makepeace Thackeray. Born in a pastor's family, Emily Jane Bronte is silent and has spent almost all his life in loneliness. The Christian atmosphere of the family environment, on the one hand, contributed to her cold, shy and lonely character; on the other hand, it also made her closer to nature, but her heart was passionate and eager to seek spiritual freedom in nature. Her hometown, Haworth, is a heather and rocky wilderness. Emily Jane Bronte, who grew up here, is deeply attached to the beauty of the wilderness. Emily is precocious and has a strong interest in literature, art, music and current affairs politics. Her sister Charlotte said: "My sister loves the wilderness. In her eyes, the darkest heather will open a flower that is more beautiful than the rose. In her heart, a dark valley on the lead-gray hillside will become a paradise on earth. She can find many loves of love in the lonely wilderness, especially freedom. Freedom is the breath in her nose. Without it, she can't live."

"Wuthering Heights" is the only novel by Emily Jane Bronte. It is another masterpiece in the history of English literature and a valuable asset in the history of art. The novelist's early death, combined with the strange feelings expressed in the novel, has given the novel a mysterious veil. Until today, the comments on this novel are still endless. The novel tells the love tragedy of the heroes of Heathcliff and Catherine. The two have no guesses and feelings. But when they are married, Catherine married the forest of the Grange, which triggered the vengeful revenge of Heathcliff. Leading to one tragedy after another. This example of a lover who can't be married is a lot in history, but Emily's same story has given readers a strong shock and a different feeling. David Cecil said: "In the Victorian novels, "Wuthering Heights" is the only classic that has not been eclipsed by the dust of time." The interpretation of the theme of "Wuthering Heights" is endless, the ecology of the twentieth century Criticism has opened up new perspectives for the study of this fascinating work. "Wuthering Heights" embodies ecological thought everywhere. The nature described in the works is different from the world described by her contemporary novelists. The natural scenery is a natural ecology with respiration, which reflects the ecological thought in 
people's life description. Describe the silence of Wuthering Mountain Villa to destroy the Meishan Villa, which is to reflect the critique of civilization. This paper analyzes the theme of the novel again from the perspective of ecological criticism, examines the relationship between nature and civilization through literary texts, rescues the nature as a living environment of human beings, and also solves the problem of human alienation by human nature.

\section{Eco-criticism in China}

Ecological criticism is a literary criticism that explores the relationship between literature and nature under the guidance of ecologically, especially ecological holism. It reveals the ideological and cultural roots of ecological crisis reflected in literary works, and also explores the ecological aesthetic and artistic expression of literature. . The object of eco-criticism is not only ecological literature, but also works that directly describe the natural landscape. From the perspective of ecological ideology and ecological aesthetics, ecological criticism re-examines and re-evaluates all the literature of the past and the present, especially the classic works that have a major impact on human civilization and social development. The task is to enrich the ecological meaning of literature, reveal the ecological limitations of literature, and promote people to establish ecological literary concepts and ecological aesthetic concepts, and promote people to form and strengthen ecological awareness and promote the construction of ecological civilization.

Literary criticism is the most active, lively and influential part of contemporary Chinese culture. Although its direct research object is literature and art, its function is not limited to reflection, adjustment, summarize and promotion of literary and artistic creation. It also plays an important role in enlightenment, dispelling traditional ideology, constructing a new humanistic spirit, and even planning the future of Chinese culture. mission. As an important research direction of literary criticism, eco-criticism has formed four distinct fields in China after more than 20 years of development: translation and introduction of Western ecological criticism, excavation and transformation of ancient ecological resources, review practice of ecological literature, and local contemporary ecological criticism. Theoretical construction attempts. Although it has achieved good results, it still has a big gap compared with Western ecological criticism, mainly in the following aspects: most of the ecological criticism works lack of conscious comparative literature consciousness, lack of interdisciplinary and Western ecological criticism. There is a certain simplification tendency in cross-culture and even across the broad perspective of civilization. When discussing Confucianism and Taoist ecological thoughts, the elucidation is not deep enough, and the two are often discussed separately. It is not discussed as a whole that Taoism and Confucianism are solving the current environmental crisis. The role of the relationship between women, nature, culture and environmental crisis is obviously insufficient; the interpretation and utilization of Chinese traditional cultural ecological resources has a tendency to simplify; the theory is obviously lagging behind, still lingers in the dual mode of human centrism and eco-centrism, there is no theoretical development based on historical and practical needs. The historical and realistic roots of the ecological crisis have not been deeply explored, and the vision and academic space of ecological criticism have not been expanded. Therefore, this paper mainly studies Western ecological criticism theory.

\section{Storyline of "Wuthering Heights"}

"Wuthering Heights" tells the story of youth and love, growth and revenge. Through the final love tragedy of the hero and heroine, it shows a pathological picture of life that is common in British society at that time, and outlines the distorted personality and various horror things caused by the abnormal real society. The whole storyline consists of four main parts:

The first part, which describes the feudal manor Catherine and the Gypsy abandoned child Heathcliff, the childhood scene in Wuthering Heights, highlights the unique emotions formed by a young lady and an abandoned child in the social environment of the time. And they are fighting against the tyrannical overbearing of Manor, the young master of the estate. 
The second part focuses on the changes in Catherine's psychology. The life of the upper class made her yearn for her, which made her more vain and ignorance. She finally turned away from the love with Heathcliff and chose to marry the eyebrow, the young master of Edgar, to become the mistress of the thrush.

The third part, with a large amount of ink, describes Heathcliff in the abyss of sorrow and despair, turning his pain into full of resentment, and finally implementing revenge plans and actions.

The fourth part, ending with the death of Heathcliff, his death reflects a kind of loyalty, and love for Catherine. When he knew that Hareton and Little Catherine fell in love, they thought of their childhood and Catherine, and they had earth-shaking changes in their minds. They gave up revenge before they died. This change is the recovery of human nature, which injects new vitality and vitality into the dark and gloomy Wuthering Heights.

\section{Natural Ecology of "Wuthering Heights"}

The nature described in Wuthering Heights is a world different from contemporary novelists. It has a certain surreal style. The activities people are engaged in are simple and simple, and life is immutable. The world in the novel is a In reality, busy people are sheltering from the harbor. The natural background is not a still life, but a natural ecology with breathing. The wilderness enjoys the sun like an animal. "The branches of the thorns grow in one direction, as if eagerly reaching out to accept the alms of the sun." The wind is mixed with snowflakes, "wildly whizzing past", the valley's stream will be soft. The voice, "soothing the soul of the people," when the fall fades away. The last flower fell down with uneasiness and sadness. These descriptions indicate that the author abandoned the conceptual basis of contemporary writers, that is, the opposition between man and nature. She believes that human beings and nature are also alive and living in the same way. This view that life reflects the natural ecology is consistent with the idea that nature is alive in ecological research.

In Wuthering Heights, the harmonious symbiosis between man and nature is presented, and it is also reflected in the influence of the wasteland on the characters. After Catherine's death, the principle of absurdity became a carrier for people to miss and remember. Linton walked in the wilderness because of sorrow. Heathcliff was sorrowful in the wilderness. The wilderness was the place where they talked about emotions, and also the medicine for treating internal trauma. The creatures of nature are human partners and friends. This view has been mentioned many times in the works. Heathcliff's fear and care for the flocks of the flock, Nail's painful puppy, etc., seems to be in the novel. Characters love and sympathize with the creatures of nature. Nature is a loyal partner of human beings. The relationship between the two is not simply complementary, but inseparable. This is also the author's understanding of the natural harmonious ecology.

\section{Social Ecology of "Wuthering Heights"}

"Wuthering Heights" can be regarded as a social ecological fable, in which nature and civilization are embodied as two distinct worlds, Wuthering Heights and Thrush. The transition from confrontation to harmony between nature and civilization is also carried out in the grievances of the characters in two different worlds. The conflict between the natural world and the civilized world began with the battle for love between Hicks and Edgar. Under the temptation of the civilized world, Catherine, who had been intimately engaged with Hick, gradually turned away from her nature and determined to marry Edgar. His marriage to Catherine and Edgar was even more double abuse and insult. Under such a double blow, Hicks left home. In the first contest between nature and civilization, the world symbolizing civilization has won a great victory.

When Hick was returning to his hometown, he had unscrupulous revenge because of the humiliation and injury he had suffered. This is the natural world's madness against the civilized world. In the revenge of Hicksman, Catherine, Hendley, Isabella and Edgar passed away, and Wuthering Heights and Thrush Grange became the property of Hicksley, in the second 
confrontation between nature and civilization. The power of nature makes civilization have no counterattack. This is a metaphor for the future that mankind is about to face. Although mankind has achieved temporary victory in controlling nature through civilization and transforming nature, if human beings can't get lost, they will one day be ruthlessly counterattacked. In the face of strong natural forces, human beings and the civilized society they represent are only destined to die.

How to coordinate the relationship between nature and civilization is the key to maintaining social and ecological balance. Human beings are the main body engaged in various social activities. Only by coordinating the relationship between people can we construct a harmonious state between nature and civilization, thus contributing to the balance of social ecology.

\section{Spiritual Ecology of "Wuthering Heights"}

"Wuthering Heights" is a tragedy of desire, which leads to the root of the tragic fate of the heroes Heathcliff and Catherine. They are strong material desires and passions that are not bound by morality and ethics. This desire makes them lose their mind and become crazy. . In the field of activity that originally belonged to spiritual space and psychological space, it was filled with matter and money. The torch of the human spirit dimmed in the flood of material, and the tragedy caused was inevitable. As a woman with flesh and blood and romantic innocence, Catherine fell into a strange circle that humans could not jump out of. The material life was rich, but the spirit was degraded. This is a spiritual problem and a kind of "spiritual pollution." "The loss of the spirit" and "the decline of the spirit" have become more and more troublesome problems for modern people.

(1) Materialism is the erosion of the spirit. Both Catherine and Heathcliff are self-willing prisoners of desire, not only making them unhappy, but also making the people around them miserable. Catherine thinks naively that money is omnipotent. He believes that marrying rich people can change the fate of Heathcliff's abuse, and the equal sign between money and happiness. Her approach seems ridiculous, but people often think that happiness is directly proportional to wealth, and the harsh reality makes people suffer, and the increase in wealth cannot represent an increase in the happiness index. On the contrary, as wealth increases, people become more empty and boring, and mental problems such as depression, arrogance and metamorphosis suddenly increase.

(2) The lust of human nature. If Catherine is married to Lin Biao, her relationship with Heathcliff is pure love, then her relationship with Heathcliff after marriage is deviated from the track of love, can only be considered lust. Love is a strong, pure and one-of-a-kind relationship between men and women based on a certain social foundation and a common ideal of life, forming an admiration in their own hearts and craving each other to become their lifelong companions. Sex, ideals and responsibilities are the three basic elements that make up love. Love without responsibility loses moral restraint and may lead the wrongfulness of the parties.

"Wuthering Heights" is the tragedy of the protagonist's indulgence of his "material desire" and "sexual desire". He has issued a profound warning to the modern people: when pursuing happiness, there is less material desire; when pursuing love, a little more morality and responsibility, human beings can obtain Spiritual wealth and eternal life.

\section{Conclusion}

The relationship between natural ecology, social ecology and spiritual ecology is mainly reflected in the "ecology". Although the three belong to different levels of performance, the essential links of the various components are similar. The ecological relationship is the survival of human beings. basis. The components of natural ecology are interrelated, and the survival of one species is often closely related to the survival of other species, and the survival of this species contributes to the existence of other species and even the entire ecosystem, forming an interdependent relationship; In this way, the existence and even development of a person in society cannot be separated from the support and help of other individuals and groups in society, and also contribute to the survival and development of other individuals and groups. With the economic and 
social development, mankind's plundering of nature has become more and more serious. This kind of demand has far exceeded the limits that nature can bear, and has triggered a series of ecological imbalances, such as soil erosion and grassland degradation, and sustainable human society. Development is under great threat. In Wuthering Heights, the author shows the critique of civilization through natural scene description and human life description, advocating people returning to nature and still living in the true colors. In order to protect the ecological environment, we must live in harmony with the natural world, respect the law of development in the natural world, and make rational use of nature, so as to ensure the endless life of human society.

\section{References}

[1] H. X. Zhang, "Construction of Ideal Personality from Theory of Ecological Poetics: On Theme of Wuthering Heights," Journal of Shenyang University(Social Science), vol. 19, no. 3, pp. 352-356, 2017.

[2] Y. Li, "Cultural Studies and Eco-criticism," Journal of Jilin TV \& Radio University, vol. 27, no. 2, pp. 124-125, 2018.

[3] N. Wang, "Eco-criticism: Definition and task," Literary Review, vol. 51, no. 1, pp. 63-68, 2009.

[4] Y. P. Wang, "A discussion on the ecological critical consciousness of Wuthering Heights," Language Planning, vol. 58, no. 23, pp. 41-42, 2013.

[5] J. Xiao, "The Sound of Harmony: An Analysis of Wuthering Heights from the Perspective of Ecocriticism," Journal of Fuqing Branch of Fujian Normal University, vol. 29, no. 4, pp. 25-28, 2009.

[6] W. J. Xia, Z. Q. Xu, "Three points of Emily's latent ecological ethics in Wuthering Heights," Literary and artistic contention, vol. 29, no. 4, pp. 174-178, 2014.

[7] J. M. Wang, "Interpretation of Wuthering Heights from the perspective of ecology," Language Planning, vol. 59, no. 3, pp. 47-48, 2014.

[8] $\mathrm{B}$. Wu, "The relationship between man and nature in Wuthering Heights and the relationship between man and nature," Journal of Chifeng University (Philosophy and Social Science Chinese Edition), vol. 37, no. 12, pp. 169-170, 2016. 